\title{
進化する社会と学問:コンピュータ化学との出会いと未来に 生きる世代への期待
}

宮本 明

東北大学未来科学技術共同研究センター，仙台市青葉区荒巻字青葉 6-6-10

(Received: November 16, 2020; Accepted for publication: February 10, 2021; Online publication: September 15, 2021)

新しい日本国憲法施行の日にうまれてから 73 年，大学卒業からでも 50 年，大学での教員・研究者とし て過ごしてきたが，その間の研究の展開について，「進化する社会と学問」の観点で纏めた．特に，コン ピュータ化学に出会ってからは, 「進化する社会と学問」を強く意識することにより, 研究推進に力を得 ることが多かった，未来に生きる世代には，それに加え，「自分の飯のタネは自分で考える」ことの大切 さを強調した。

キーワード: 触媒, 環境, コンピュータ化学, 産学連携, 研究者の生き方

\section{1 はじめに}

コンピュータ化学会創立20周年おめでとうございま す.また，その機会に寄稿の機会も与えて頂き，御礼申 し上げます.コンピュータ化学会誌には，退職を機会に 記念誌をご出版頂き，永年共同研究者等としてお世話に なった方々のご投稿も頂き，感謝しています [1]. その 後も, 東北大学未来科学技術共同研究センター $(\mathrm{NICHe})$ の外部資金による教授・プロジェクトリーダーを続けて いましたが，70歳でそれも定年，73歳の今は， NICHe のシニアリサーチフェローとして，若手研究者を支援す る立場です．折しも，大学卒業 50 周年にも当たりますの で，これまでの歩みを「進化する社会と学問」という観 点から振り返り，未来に生きる世代へのメッセージ，期 待を述べたいと思います。

\section{0 年余の大学での実体験を通して 考える「進化する社会と学問」}

\section{1 憲法施行日の誕生から大学院修了までの歩 み:新しい日本とともに}

1945 年 8 月 15 日の終戦を経て，1947年 5 月 3 日に，新 しい日本国憲法が施行されたが，それが自分の誕生日で
もある. ベビーブーム(団塊)世代であるので, 憲法だけ でなく，様々な面で新しい制度とともに歩んだ。中学卒 業後に 5 年間学んだ国立鈴鹿工業高等専門学校もその一 つであった. 5 年間の一貫教育で, 大学の工学部卒業レ ベルに到達させるべく, 先生方もとても意欲的で, 数学, 英語, ドイツ語, 化学, 物理, 卒業研究などの教育を受 けたことは振り返ってみると貴重な体験であった.

鈴鹿高専での学習を通して，もっと梁く勉強してみた いという気持ちをもっていた時に, 東北大学工学部が編 入生を受け入れるという情報を得て，5年生の 1 月の編 入学試験を受け, 高専から編入学 1 期生として東北大学 工学部 3 年生で学ぶ機会を得た. 当時は何処の大学でも 学園紛争が盛んで, 東北大学でも 3 年生の前期には, か なりの時間がストライキ, 学生討論などが行われ, 大学 に来たことを実感することになった，その中で語られる 様々な内容に興味をもち, 歴史, 経済, 心理学, 哲学, 数学, 量子力学, 相刘性理論など社会の基礎, 科学の基 礎をもっと深く勉強する機会を得たことは幸せなことで あった. 研究室配属は, 高専での経験もあり, 触媒を専 門とされる荻野研究室を志望した。「液体金属の触媒作 用」という全く新しい研究テーマを頂き, 主体的に, 研 究手法, 解析手法, 実験装置の製作を行い，金属系，物 理系, 東工大, 北大, 名大などの研究者, 学生と交流し 
た. 下宿近くのキャンパスには, 大型計算機センターが 開設, FORTRANプログラムによる反応器の流体力学的 解析, 量子化学的解析も進めた. 研究にとって必要とな る様々な基礎と主体的に学問を進める楽しさを習得する 時代であった.

\section{2 名古屋大学助手時代: 環境触媒研究を通し て，進化する社会と学問を実感}

1975 年 4 月, 名古屋大学工学部合成化学科村上研究室 の助手となった．日本国憲法施行の日に生まれたことに より, 当時の考えが朝日新聞記事(1997年5月2日:施行 日生まれの50歳にきく)になっているので，それを引用 する。「東北大の博士課程を終えて 1975 年に名古屋大の 助手になった. 教授から与えられたテーマは, 火力発電 所から出る有害物質を取り除く研究だった. 光化学又 モッグや四日市ぜんそくなど公害が社会問題になってい た時代でも，モノ作りに直接結びつかない環境保護のた めに研究は傍流だった，それを生涯のテーマにしていけ るかどうか，迷った時，憲法の施行日に生まれた偶然を 意識した．平和憲法の理念を技術に生かすのが自分の使 命と考え，迷いが吹っ切れた.」このようにして始めた 環境触媒研究であるが，その成果が一連の論文として発 表される頃になると，世界的な注目を集め, アメリカ, ヨーロッパの多くの大学, 研究所に招待され講演を行 い，夕食会などにも招かれた。 日本を先頭に世界的に環 境触媒の重要性が急速に高まったお蔭であるが, 社会と 学問の関係, 進化を哚く考える貴重な機会となった.

\section{3 京都大学助教授時代:コンピュータ化学開始 を通して，進化する社会と学問の理念を研 究者としての生き方に}

1985 年 5 月には, 京都大学工学部石油化学科乾研究室 に助教授として着任した．石油化学科教授を務められた 福井謙一先生がノーベル賞を受賞された直後であった ので, その時の興奮と高揚が強く残っていた. 石油化学 教室レベルでは, 乾先生を中心とする概算要求が行わ れた. 理論研究と実験研究の協奏効果を発揮させるた めの研究設備の要求であり, 私は世話役を務めた. 種及 の構造解析装置に分子設計システムを加えた設備要求で あるが，高く評価され，実現することになった．実験装 置については, 担当者が直ぐに決まったが, 分子設計シ
ステムは希望も無く私が担当することになった，名大時 代の成功体験だけでなく, 要求書を䌕める過程で, コン ピュータ化学に大きな可能性を感じ取ることが出来たの で，積極的に取組むことにした．これについても成果を 発表する頃になると早速，大きな反響を得ることが出来 た.

\section{4 東北大学教授時代: 進化する社会と学問の理 念を研究発展の力に:学問を社会に生かし, 社会課題から新しい学問を育む}

コンピュータ化学に対する大きな期待もあり，1992年 4月からは東北大学工学部分子化学工学科教授となった. 学科名, 講座名は変わっているが, 学生時代の荻野研の 後継である. 新しい講座ではないので, コンピュータ化 学に必要な設備購入費はなかった，多額の借金をして最 低限の設備を整え, 新しい研究室をスタートした。「新 しい研究室をつくる:研究室の運営はこんなにたいへん」 化学，48, 240 (1993)などでも紹介頂き, それに応えて, 若手教員, 学生も大活躍, 多くの産学官のリーダーのご 支援を得ながら大きな研究室を構筑することが出来た. 外国人教員の採用による学生, 若手教員の国際化, 多数 の研究員, 技術補佐員, プログラマーの雇用, 国内外の 多様な企業との産学連携, 国内外の大学との連携による 人材育成と基礎研究の推進など，大学研究室としての新 しい取組みも進めた。2002年には産学連携拠点して期待 の高まっていた未来科学技術共同研究センター $(\mathrm{NICHe})$ の専任教授になり，国内外からの注目も高まった。 その 結果, 科研費など基礎研究だけでなく, 多くの産学連携 の大型プロジェクトにも選ばれるとともに，コンビナト リアル計算化学寄附講座も合わせ, 多いときには 200 名 を超えるような組織を作り上げることが出来た．多彩な 学問分野を背景とする国内外からの多くの若手教員, 国 内外からの多彩な産業社会分野の客員教授, 世界各国 からの留学生, 多くの企業からの社会人博士, プログラ マー, 技術補佐員などのスタッフが充実すると, コン ピュータ化学を自動車, 半導体・エレクトロニクス, 環 境, 機械産業, 電池, 化学, 原子力, スノースポーツ, トイレなど住宅設備, 建築, 医療など多彩な産業分野に 展開するとともに，そのための多くのソフトウエアの構 築が進んだ.さらにそれが多彩な産学官連携研究も生み 出した。「学問を社会に生かし, 社会から新しい学問を 育む」という目標も生まれた。2012年には文科省定員の 
教授は定年となったが，外部資金による $\mathrm{NICHe}$ 教授・プ ロジェクトリーダーとして多くのメンバーとともに様々 な産学連携研究をそれも定年となる2018年まで続けた。

\section{3 未来を生きる世代への期待: 自分の 飯のタネは自分で考える}

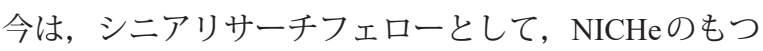
先進的なミッションを進化し続ける社会の中で若いリー ダーに逞しく継承発展して頂くよう新しい活動を進めて いる.

その中で若い世代はどのような可能性があるか. 今 は，73歳になってしまっているが，自分にも若い時があ り，その時に同世代の若手メンバーと生き方について議 論したことがあったので紹介したい.。化学工学会での 取組であったが, その後, 東大の総長にもなられた小宮 山宏先生の呼び掛けで, 当時, コンピュータ化学への道 筋を歩み始めていた京大助教授時代の私がお世話役を務 めた. メンバーは, 化学工学会の中で, 私よりは若い世 代であった，それぞれが，自分が考える将来の学問につ いて, 調査結果を報告しあった，その時に，共通の考え 方が，「自分の飯のタネは自分で考える」であった．同 じ化学工学という分野ではあるが，それぞれの若手研究 者の個別分野では, 多様な発展可能性があるので, それ ぞれが，自分の飯のタネは自分で考えるのがよい，とい うことになり，それぞれにより多様な発展への道筋が描 かれた. 結果として, このグループの中からは, 大きく 発展する研究者が多く生まれた.

「自分の飯のタネは自分で考える」ことは当たり前で 簡単なように思えるかも知れないが, 実践的には結構困 難も少なくない．東北大学で新しい研究室を展開し始め た頃,「私の研究観」という題での寄稿を求められた [2].
その中で,「競争はできるだけしない」,「残り物に福が ある」,「火のない所に煙をたてる」,「自己革新に挑戦す る」,「賛成者が多いようなことはやらない,「先ず持っ ているものを捨てないと, 新しいものは掴めない」,「一 番の幸せは人々に喜んでもらえること」など掲げている が，その中で「賛成者が多いようなことはやらない」の 一節を引用する. 若い研究者にとって問題なのは, 陽の あたる分野が好きであることであろう．自分の発表を多 くの人が注目し賞賛するとその分野から離れられなくな る. 発表しても誰も聞いてくれなかったり，無視された りするとやる気をなくしてしまう，賛成者，賞賛者の多 いような研究は往々にして既に成熟分野となり，大きな 発展が期待できない場合が少なくない，むしろ自分のこ とを真剣に心配してくれる人でさえ反対するような未開 拓の分野に挑戦することが新しい研究の発展, 飛躍に繫 がる.

コンピュータ化学会に関係する未来に生きる世代に も，同じ言葉を贈りたい，様々な形で大きく発展する可 能性のあるコンピュータ化学関連分野で, それぞれが, 「進化する学問と社会」も念頭に,「自分の飯のタネは自 分で考え」, 逞しい歩みを続け, 大きなインパクトを与 えられるよう期待している，それぞれの価值観，考え方 を入れて歴史の流れの中で独自の貢献をすることが出来 ることは素晴らしいことと思う。同時にそれにより, 社 会の困難の解決に貢献したり, 新しい産業が生まれた り，生き甲斐をもって進める人が生まれたりする喜び は, 何物にも代えがたいように思う. 若い世代への期待 は尽きない。

\section{Reference}

[1] M. Kubo, ed., J. Comput. Chem. Jpn., 12, A1, 1 (2013).

[2] A. Miyamoto, Business Research, 1998-6, 71 (1998). 


\title{
Evolving Society and Academy in Computational Chemistry and Expectations for Younger Generations
}

\begin{abstract}
Akira MIYAMOTO
New Industry Creation Hatchery Center, Tohoku University 6-6-10 Aoba Aramaki Aobaku Srendai 980-8579 Japan

On the occasion of $20^{\text {th }}$ year anniversary of computational chemistry society of Japan, based on more than 50 years research experiences in both experimental and computational fields, evolution of research topics and methodology was discussed in terms of social evolution including the importance of environmetal technology and compotational methods. Start of computational chemistry gave significant impact on the progress of research activities of the authors group including many industry/academy collaborations for a variety of social/industrial topics and these collaborations further promoted the progress of computational methodologies to succesfully perform the collaborations. The own idea for the research topics/methodologies is emphasized highly important for younger reserachers in addition to the deep understanding of evolving society and academy.
\end{abstract}

Keywords: Catalyst, Environment technology, Computational chemistry, iIndustry-academy collaboration, Research development, Research philosophy 